\title{
Construction of differential expression plasmids of NGF to detect its influence on PC12 cell neuronal differentiation
}

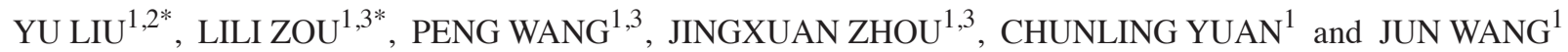 \\ ${ }^{1}$ Central Laboratory, The People's Hospital of China Three Gorges University, Yichang, Hubei 443000; \\ ${ }^{2}$ Department of Oncology, Gong'an County Hospital, Jingzhou, Hubei 434300; ${ }^{3}$ Infection and Inflammation Institute, \\ Medical College, China Three Gorges University, Yichang, Hubei 443002, P.R. China
}

Received April 18, 2019; Accepted November 13, 2020

DOI: $10.3892 / \mathrm{etm} .2021 .9794$

\begin{abstract}
Alongside angiogenesis and lymphangiogenesis, neurogenesis also occurs within the cancer microenvironment. Neurogenesis is a complex process involving multiple factors, among which nerve growth factor (NGF) possesses the dual biological roles of neuron nutrition and axon growth promotion. Thus, NGF might be a key molecule involved in regulating cancer-related neurogenesis, which could play a crucial role in the signal transmission system that controls nerve growth in tumors, and enhances the abilities of migration, invasion and metastasis of tumor cells. The present study aimed to construct differential expression plasmids of NGF, in order to detect whether NGF has a vital role in neurogenesis in breast cancer cells. In the present study, 92 clinical cases of breast cancer were collected and immunohistochemical analysis was performed to verify the existence of neurons in the breast cancer microenvironment. Furthermore, recombinant NGF lentiviral overexpression, knockout and silencing plasmids were constructed, and whether NGF has an effect on neuron growth was preliminarily confirmed, indicating that the successfully constructed plasmids could be used to verify the roles of NGF in cancer-associated neurogenesis.
\end{abstract}

\section{Introduction}

Perineural invasion was traditionally considered as the primary type of interaction between tumor cells and nerve cells in the tumor microenvironment, and is considered critical in the invasion and metastasis of pancreatic, colorectal and gastric cancer, as well as other malignant tumors $(1,2)$. Previous

Correspondence to: Dr Jun Wang, Central Laboratory, The People's Hospital of China Three Gorges University, 2 Jiefang Road, Yichang, Hubei 443000, P.R. China

E-mail: wangjfox@gmail.com

${ }^{*}$ Contributed equally

Key words: breast cancer, cancer-related neurogenesis, nerve growth factor, recombinant nerve growth factor plasmids studies showed that there is a new way of communication between tumor cells and nerve cells, which is called tumor cell-mediated neurogenesis (3-6). In addition, newborn nerves stimulate the proliferation and metastasis of tumor cells. In 2008, Ayala et al (7) described the phenomenon of neurogenesis in prostate cancer, and defined cancer-associated neurogenesis and cancer-related axonogenesis. The newborn nerves were revealed to act as 'channels', leading to the migration of tumor cells, which is closely associated with metastasis and degeneration of tumors $(5,7)$. A similar phenomenon has recently been reported in which the co-culture of dorsal root ganglion (DRG) cells with pancreatic cancer cells led to a significant increase in the density of DRG neurons (8). Under these conditions, tumor cells could not only proliferate rapidly, but also showed a tendency to grow close to the DGR cells, which suggested that tumor cells can stimulate nerve growth $(8,9)$. In 2013, Magnon et al (5) confirmed that the sympathetic nerves could release norepinephrine to activate the $\beta 2$ and $\beta 3$ adrenergic receptors, leading to the onset of prostate cancer; whereas parasympathetic nerve-released acetylcholine could bind to type I muscarinic receptor to promote the proliferation and metastasis of prostate cancer. Since then, numerous pathological studies have observed the existence of newly developed nerves in a variety of malignant tumors $(4-6,10,11)$. Although the associated mechanisms have not been elucidated yet, the understanding of cancer-related neurogenesis may provide a novel approach for cancer treatment.

Neurogenesis is a complex process involving numerous factors, and the growth of axons serves a crucial role in it (12). New axons need neurotrophins to promote their growth, and axon guidance cues guide them to extend to specific areas $(13,14)$. It is worth noting that nerve growth factor (NGF) is one of the most important members of the neurotrophic factor family. It possesses dual biological functions of neuron nutrition and axon growth promotion, and plays important regulatory roles in the development, differentiation, growth and regeneration of neurons (15). Meanwhile, protein gene product 9.5 (PGP9.5) is a ubiquitin hydrolase, which regulates cellular processes in the cell hydrolysis pathway, including cell cycle division and cell death (16). Previous studies have detected a high expression of PGP9.5 in numerous tumors, including colorectal, pancreatic, esophageal and bladder cancer (16-18). In a previous study, in tumor tissues, PGP9.5 
induced an increase in cyclin ubiquitination resulting in uncontrolled growth of undifferentiated cells, which is one of the key factors leading to oncogene activation (19).

An increasing number of studies have confirmed that tumor cells can obtain NGF through autocrine and paracrine routes to assist their survival, proliferation and metastasis. For example, several types of cancer cells, including breast cancer, have been shown to produce autocrine NGF, and its high mRNA and protein expression levels in these cells have been confirmed (20). Of note, NGF binding receptors in cancer cells are highly consistent with the receptors in nerve cells, which are able to bind to tropomyosin receptor kinase $\mathrm{A}$ and p75 neurotrophin receptor, to mediate the survival and proliferation of tumor cells (20-22). In addition, paracrine NGF from breast cancer cells could affect the growth and development of adjacent neurons in addition to their own (20). It has been reported that NGF can effectively induce the differentiation of embryonic neural precursor cells (20), and the overexpression of proNGF in prostate cancer tissue could also effectively induce neurogenesis (21).

In certain tumor cells, including breast cancer cells, autocrine NGF has been shown to not only be involved in their development, but may also affect the growth and development of neighboring neurons through the paracrine system. Thus, NGF may be a key molecule involved in regulating cancer-related neurogenesis, which might play a crucial role in the signal transmission system that controls the related nerve tumor growth, and enhances the migration, invasion and metastasis of tumor cells. In the present study, PGP9.5 was used as a neuronal marker, and its positive expression level was scored. Furthermore, recombinant NGF lentiviral overexpression, knockout and silencing plasmids were constructed, and whether NGF affects neuron growth was investigated and preliminarily confirmed. Furthermore, the successfully constructed plasmids could be used to verify the hypothetical roles of NGF in cancer-associated neurogenesis and cancer-related axonogenesis.

\section{Materials and methods}

Expression of PGP9.5 in breast cancer. In total, 92 immunohistochemically identified breast cancer tissues were collected from patients (age, 24-79 years; mean age, 51.5 \pm 12 years) at the First College of Clinical Medical Science, China Three Gorges University (Yichang, China) between October 2014 and November 2015; patients provided written informed consent and the study was approved by the Ethics Committee of the First Affiliated Hospital of Three Gorges University. Patients could be any age and pathological grade, and with or without metastasis (Table SI). Samples were used to perform immunohistochemistry using recombinant anti-PGP9.5 antibody (cat. no. ab109261; Abcam). The clinical data of the specimens were classified by patient age, tumor size and degree of differentiation, which in turn was classified according to the Nottingham system (Table I) (23). Immunohistochemistry was carried out according to the EnVision two-step method as previously described (24), and PBS was used as a negative control. PGP9.5 was used as a neuronal marker, and its positive expression level was scored according to the following positive criteria: Cells that contain brown and yellow granules in
Table I. Relationship between PGP9.5 expression and the clinicopathological features of breast cancer.

\begin{tabular}{lccc}
\hline Characteristics & Total cases & Positive rate (\%) & P-value \\
\hline $\begin{array}{l}\text { Age (years) } \\
\quad 50\end{array}$ & 44 & $39(88.6)$ & 0.867 \\
$\quad>50$ & 48 & $42(87.5)$ & \\
Tumor size $(\mathrm{cm})$ & & & \\
$\quad \leq 2$ & 58 & $50(86.2)$ & 0.707 \\
$>2$ & 34 & $31(91.2)$ & \\
Pathological grade & & & \\
I & 29 & $21(72.4)$ & 0.005 \\
II-III & 63 & $60(95.2)$ & \\
\hline
\end{tabular}

Statistical analysis was assessed by $\chi^{2}$ test. $\mathrm{P}<0.05$ was considered to indicate a statistically significant difference.

the cytoplasm were considered positive, and the total number of positive cells in 100 cells in every five fields of view was counted. The average value was calculated and further scored according to the staining intensity and the number of positive cells. The staining intensity criteria were as follows: 0 was considered negative, where there were no brown and yellow granules in the cytoplasm; 1 was considered weakly positive, with light yellow granules; 2 was considered positive, with yellow granules; and 3 was considered strongly positive, with brown and yellow granules. The number of positive cells was scored according to the following criteria: 0 was considered absence of positive cells; 1 was assigned when the percentage of positive cells was $<25 \%$; 2 corresponded to $25-50 \%$ positive cells; and 3 was assigned if the percentage of positive cells was $>50 \%$.

Construction of recombinant NGF lentiviral overexpression plasmids. MDA-MB231 and T-47D cell lines (The Cell Bank of Type Culture Collection of the Chinese Academy of Sciences) were cultured in a $5 \% \mathrm{CO}_{2}$ incubator at $37^{\circ} \mathrm{C}$ with DMEM (high-glucose) (cat. no. 31053028; Gibco; Thermo Fisher Scientific, Inc.) containing $10 \%$ fetal bovine serum (cat. no. 10099141; Gibco; Thermo Fisher Scientific, Inc.) and $1 \%$ pen/strep. Genomic DNA of the breast cancer cell lines MDA-MB231 and T-47D was obtained using Ezup Column Animal Genomic DNA Purification kit (cat. no. B518251; Sangon Biotech Co., Ltd.), which was subsequently used to construct recombinant pMD18-T-NGF plasmids using the pMD $^{\text {TM }}$ 18-T Vector Cloning kit (cat. no. 6011; Takara Bio, Inc.) with the primers listed in Table II. Recombinant pMD18-T-NGF was sequenced and used as a template to amplify NGF and NGF-FLAG. The PCR cycling conditions were as follows: Initial denaturation at $95^{\circ} \mathrm{C}$ for $5 \mathrm{~min}$; followed by 34 cycles at $95^{\circ} \mathrm{C}$ for $40 \mathrm{sec}, 56.2^{\circ} \mathrm{C}$ for $50 \mathrm{sec}$ and $72^{\circ} \mathrm{C}$ for $30 \mathrm{sec}$; and a final extension at $72^{\circ} \mathrm{C}$ for $5 \mathrm{~min}$. The FLAG-labeled NGF (PCR product of pMD18-T-NGF-FLAG) was further linked to pCDH-CMV-MCS-EF1-puro (\#vt1480; YouBio) to construct the recombinant FLAG-labeled NGF overexpression plasmid pCDH-CMV-MCS-EF1-puro-NGF-FLAG 
Table II. Recombinant overexpression NGF primer pairs.

Restriction

Primer name

Sequences $\left(5^{\prime}-3^{\prime}\right)$

enzyme

pCDH-NGF-F

pCDH-NGF-R

pCDH-NGF-FLAG-F

pCDH-NGF-FLAG-R
TGCTCTAGAATGTCCATGTTGTTCTACACTCTG

CGCGGATCCTCAGGCTCTTCTCACAGCCTT

TGCTCTAGAATGTCCATGTTGTTCTACACTCTG

CGCGGATCCTCACTTATCGTCGTCATCCTTGTAATCGGCCTTCTCACAGCCTT
BamHI

$\mathrm{Xba \textrm {I }}$

F, forward; R, reverse; NGF, nerve growth factor.

(pCDH-NGF-FLAG) with XbaI/BamHI enzyme loci. NGF (PCR product of pMD18-T-NGF) was also directly linked to pCDH-CMV-MCS-EF1-puro to construct the NGF overexpression plasmid pCDH-CMV-MCS-EF1-puro-NGF (pCDH-NGF). Furthermore, $3 \mu \mathrm{g}$ proteolipid protein (pLP)1, $3 \mu \mathrm{g} \mathrm{pLP} 2$ and $3 \mu \mathrm{g}$ pLP/VSVG from ViraPower ${ }^{\mathrm{TM}}$ Lentiviral Packaging Mix (cat. no. K4975-00; Invitrogen; Thermo Fisher Scientific, Inc.), $3 \mu \mathrm{g}$ pCDN-NGF, $3 \mu \mathrm{g}$ pCDN-NGF-FLAG, $3 \mu \mathrm{g}$ pCDH-puro and $3 \mu \mathrm{g}$ pCHD-EGFP were transfected

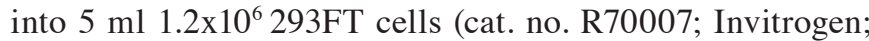
Thermo Fisher Scientific, Inc.) using $36 \mu 1$ Lipofectamine ${ }^{\circledR}$ 2000 reagent (Thermo Fisher Scientific, Inc.), and incubated overnight at $37^{\circ} \mathrm{C}$ in a humidified $5 \% \mathrm{CO}_{2}$ incubator, according to the manufacturer's protocol, and the vector (pCDH-puro) was used as a negative control. After $72 \mathrm{~h}$, the supernatants were collected, sterilized by filtration $(0.45 \mu \mathrm{m}$ filter; cat. no. SLHV033RB; EMD Millipore) and were used to infect the breast cancer cell lines MDA-MB231 and T-47D $\left(2.5 \times 10^{6}\right.$ cells; twice, every $\left.24 \mathrm{~h} ; \mathrm{MOI}, 8\right)$ at $37^{\circ} \mathrm{C}$, and bright field and fluorescence microscopy were used to detect the infection efficiency. After $48 \mathrm{~h}$, the infected cells were used to screen target cells by puromycin selection; 2 and $6 \mu \mathrm{g} / \mathrm{ml}$ puromycin were used for MDA-MB-231 and T-47D, respectively. The puromycin-screening time was determined according to the results of a preliminary puromycin-resistance experiment.

The puromycin-screened breast cancer cells, including the overexpression (pCDH-NGF and pCDH-NGF-FLAG), vector (pCDH-puro) and untransfected groups (MB231 and T-47D cells), were seeded onto $100-\mathrm{mm}$ culture plates $\left(2.5 \times 10^{6}\right.$ cells in DMEM in triplicate. After 72 -h incubation at $37^{\circ} \mathrm{C}$, the cells were collected, and the RNA was extracted by RNAsimple kit (cat. no. DP419; Tiangen Biotech Co., Ltd.), according to the manufacturer's instructions, and reverse transcribed into cDNA using the Takara Reverse Transcriptase kit (cat. no. RR036Q; Takara Bio, Inc.). The reverse transcription (RT) conditions were $65^{\circ} \mathrm{C}$ for $5 \mathrm{~min}, 42^{\circ} \mathrm{C}$ for $40 \mathrm{~min}$ and $70^{\circ} \mathrm{C}$ for $15 \mathrm{~min}$. GAPDH was used as the internal reference (GAPDH primer sequence: forward, 5'-AGGTGAAGGTCGGAGTCA-3' and reverse, 5'-GGTCATTGATGGCAACAA-3') to normalize NGF expression. Fluorescence quantitative PCR (qPCR) [TB Green Premix Ex Taq II (Tli RNase H Plus); cat. no. RR820A; Takara Bio, Inc.] was performed to detect the expression levels of NGF with the following primers: forward, 5'-GGC AGACCCGCAACATTACT-3'and reverse, 5'-CACCACCGA CCTCGAAGTC-3' using a CFX96 Touch $^{\mathrm{TM}}$ Real-Time PCR Detection system (Bio-Rad Laboratories, Inc.) as follows:
Initial denaturation at $95^{\circ} \mathrm{C}$ for $5 \mathrm{~min}$; followed by 34 cycles of $95^{\circ} \mathrm{C}$ for $30 \mathrm{sec}, 56^{\circ} \mathrm{C}$ for $60 \mathrm{sec}$ and $72^{\circ} \mathrm{C}$ for $60 \mathrm{sec}$; and a final extension at $95^{\circ} \mathrm{C}$ for $5 \mathrm{sec}$. The results were quantified using the $2^{-\Delta \Delta \mathrm{Cq}}$ method (25).

Measurement of NGF expression levels by ELISA and western blotting. The overexpression (pCDH-NGF-FLAG), vector (pCDH-puro) and untransfected (MDA-MB231 or T-47D cells) groups were seeded $\left(2.5 \times 10^{6}\right.$ cells in DMEM $)$ onto $100-\mathrm{mm}$ culture plates in triplicate. After 72 -h incubation at $37^{\circ} \mathrm{C}$, the cell supernatants from the vector and normal groups were collected $(\sim 8.5 \mathrm{ml}$ per dish) and analyzed with a human NGF- $\beta$ ELISA kit PicoKine (cat. no. EK0469; Boster Biological Technology) using their original concentrations, whereas the supernatants obtained from the overexpression group were diluted 1:200 and further detected in parallel with the other groups using the same ELISA kit. ELISA was conducted according to the manufacturer's protocol.

In addition, proteins from cell supernatants were concentrated using $15-\mathrm{ml} \mathrm{3-kDa}$ ultrafiltration centrifuge tubes (cat. no. UFC900396; EMD Millipore) at 5,000 x g for $20 \mathrm{~min}$ at $4^{\circ} \mathrm{C}$. The protein concentrations were determined with a BCA Protein Assay kit (cat. no. P0010; Beyotime Institute of Biotechnology). A total of $25 \mu \mathrm{g}$ proteins from each group were incubated with SDS loading buffer at $95^{\circ} \mathrm{C}$ for $10 \mathrm{~min}$ and then separated by SDS-PAGE on 15\% gels. Proteins were then transferred to nitrocellulose membranes, which were blocked with $5 \%$ skim milk for $1 \mathrm{~h}$ at room temperature. The protein expression levels of NGF- $\beta$ in the pCDH-NGF-FLAG group were detected with rabbit anti-FLAG antibody $(1: 1,000$; cat. no. F7425; Sigma-Aldrich; Merck KGaA) in TBS-0.1\% Tween-20 overnight at $4^{\circ} \mathrm{C}$, followed by detection with IRDye $^{\circledR} 680$ LT goat anti-rabbit $(1: 20,000$; cat. no. 926-68021; LI-COR Biosciences) at room temperature for $2 \mathrm{~h}$. The protein expression of $\beta$-actin (rabbit polyclonal antibody; 1:1,000; cat. no. D110001; Sangon Biotech Co., Ltd.) was used as the internal reference, and the protein bands were visualized on the CLx Dual-color Infrared Laser Imaging system (Odyssey ${ }^{\circledR}$; LI-COR Biosciences). RealBand 3-color High Range Protein Marker (cat. no. C620014-0250; Sangon Biotech Co., Ltd.) was used as a marker.

Construction of recombinant NGF lentiviral CRISPR/Cas 9 knockoutplasmids.NGF-guide(g)RNA1,-gRNA2 and-gRNA3 were designed and synthesized by Sangon Biotech Co.,Ltd., and used for the construction of recombinant NGF-CRISPR/Cas9 
Table III. NGF-gRNA primer pairs.

Primer name

Sequences $\left(5^{\prime}-3^{\prime}\right)$

NGF-gRNA1-F
NGF-gRNA1-R
NGF-gRNA2-F
NGF-gRNA2-R
NGF-gRNA3-F
NGF-gRNA3-R
NGF-gRNA-F ${ }^{\mathrm{a}}$
NGF-gRNA-R
Lenti-CRISPR-NGF-F
Lenti-CRISPR-NGF-R
MV-CRISPR-NGF-F
MV-CRISPR-NGF-R
GAPDH-F
GAPDH-R

CACCGCGATAGCTGCACGCGTGGCG AAACCGCCACGCGTGCAGCTATCGC CACCGAGCTTTTCTGATCGGCATAC AAACGTATGCCGATCAGAAAAGCTC CACCGTCGCCGCTTTTTAAACAGCC AAACGGCTGTTTAAAAAGCGGCGAC CACCGGCGTCGGAGCGGCAGAACTC AAACGAGGCGGTACGGACGGCCGCC TTCGGGTTTATTACAGGGACA GACTGTGGGCGATGTGC GTGCATAGCGTAATGTCCAT CTATAAATTACCATGCAGTCCTT AGGTGAAGGTCGGAGTCA GGTCATTGATGGCAACAA

F, forward; R, reverse; NGF, nerve growth factor; gRNA guide RNA. 'aRNAs refers to negative control.

plasmids. The non-sequencing NGF-gRNA was used as a negative control. Exon 3 of NGF was the targeted exon, which affected the signal peptide domain. The designed NGF-gRNAs (Table III) were annealed and linked to the cas9 vector lentiCRISPRv2 (cat. no. 52961; Addgene) to construct LentiCRISPRv2-NGF-gRNAs (-1/2/3, non-sequencing). The constructed recombinant plasmids were validated by ampicillin resistance, appearing at the correct molecular weight on a $1 \%$ agarose gel and sequenced by a commercial company (Sangon Biotech Co., Ltd.).

The verified $3 \mu \mathrm{g}$ LentiCRISPRv2-NGF-gRNA2/3 (sequencing proved the gRNA1 was incorrect), $3 \mu \mathrm{g}$ pCMV-VSV-G (cat. no. 8454; Addgene), $3 \mu \mathrm{g}$ pLJM1-EGFP (cat. no. 19319; Addgene), $3 \mu \mathrm{g}$ psPAX2 (cat. no. 12260; Addgene) and $3 \mu \mathrm{g}$ negative control (non-sequencing gRNA) were transfected into $5 \mathrm{ml} 1.2 \times 10^{6} 293 \mathrm{FT}$ cells by $36 \mu \mathrm{l}$ Lipofectamine 2000 . After a $7-\mathrm{h}$ incubation at $37^{\circ} \mathrm{C}$, the cell supernatants were collected, filter sterilized and used to infect the breast cancer cell lines MDA-MB231 and T-47D (2.0x $10^{5}$ cells $/ \mathrm{ml}$; MOI, 8 ; twice, every $\left.24 \mathrm{~h}\right), 48 \mathrm{~h}$ post-infection, the infected cells were further used to screen target cells by puromycin selection as described in NGF overexpression section. After puromycin selection the infected single clone was further sorted using flow cytometry (MoFlo Astrios EQ Cell Sorter; Beckman Coulter, Inc.).

To select the target cells that had been correctly CRISPR/Cas9-edited by NGF-gRNA2/3, the genomic DNA of sorted cells was obtained by Ezup Column Animal Genomic DNA Purification kit (cat. no. B518251; Sangon Biotech Co., Ltd.) and used as template to perform standard PCR (EXTaq; cat. no. RR001A; Takara Biotechnology Co., Ltd.). The PCR cycling conditions were as follows: Initial denaturation at $95^{\circ} \mathrm{C}$ for $5 \mathrm{~min}$; followed by 34 cycles of $95^{\circ} \mathrm{C}$ for $40 \mathrm{sec}, 56^{\circ} \mathrm{C}$ for $50 \mathrm{sec}$ and $72^{\circ} \mathrm{C}$ for $54 \mathrm{sec}$; and a final extension at $72^{\circ} \mathrm{C}$ for $5 \mathrm{~min}$. The standard PCR NGF primers used are presented in Table II, and the NGF was detected by $2 \%$ agarose gel electrophoresis and visualized by ethidium bromide (cat. no. A600195; Sangon Biotech Co., Ltd.). Furthermore, 1.2×10² PCR-verified cells were seeded onto 96-microwell plates in triplicate. Then, the cells were collected from different wells to verify NGF (726 bp) by standard PCR, and the open-reading frame (ORF) of NGF was further sequenced (Sangon Biotech, Co., Ltd.) to verify the CRISPR/Cas9-edited cells. After three rounds of selection by sorting, PCR and sequencing, as aforementioned, the CRISPR/Cas9-edited mutants (MDA-MB231-E3-A and MDA-MB231-E3-B) cells were verified.

CRISPR/Cas9-edited MDA-MB231-E3-A and MDA-MB231-E3-B cells were seeded onto 60-mm culture plates $\left(2.5 \times 10^{5}\right.$ cells in $5 \mathrm{ml}$ DMEM) in triplicate. After 72-h incubation at $37^{\circ} \mathrm{C}$, total cell RNA was collected for NGF qPCR as aforementioned, and GAPDH was used as the internal reference. The cycling conditions were as follows: Initial denaturation at $95^{\circ} \mathrm{C}$ for $5 \mathrm{~min}$; followed by 35 cycles of $95^{\circ} \mathrm{C}$ for $30 \mathrm{sec}, 56^{\circ} \mathrm{C}$ for $60 \mathrm{sec}$ and $72^{\circ} \mathrm{C}$ for $60 \mathrm{sec}$; and a final extension at $95^{\circ} \mathrm{C}$ for $5 \mathrm{sec}$.

Construction of recombinant lentiviral NGF-silencing plasmids. The NGF-short hairpin (sh)RNA1/2/3 and non-targeting negative control shRNA were designed (Table IV) and synthesized by Sangon Biotech, Co., Ltd; these sequences were annealed $\left(95^{\circ} \mathrm{C}\right.$ for $4 \mathrm{~min}$ and $70^{\circ} \mathrm{C}$ for $\left.10 \mathrm{~min}\right)$ and linked to the lentiviral vector pLKO.1-TRC (cat. no. 10878 Addgene). pLKO.1-NGF-shRNA1, -shRNA2, -shRNA3 and negative shRNA were further verified by ampicillin-resistance, double enzyme digestion assays by EcoRI and NcoI, and sequenced (Sangon Biotech, Co., Ltd.). The non-targeting shRNA was used as a negative control.

Verified $3 \mu \mathrm{g}$ pLKO.1-NGF-shRNA1/3 (sequencing proved that shRNA2 was incorrect), $3 \mu \mathrm{g}$-shRNA (non-targeting shRNA as the negative control), $3 \mu \mathrm{g}$ pLP1, $3 \mu \mathrm{g}$ pLP2, $3 \mu \mathrm{g} \mathrm{pLP} / \mathrm{VSVG}$ and $3 \mu \mathrm{g}$ pLKO.1 were transfected into $5 \mathrm{ml} 1.2 \times 10^{6} 293 \mathrm{FT}$ cells using $36 \mu \mathrm{l}$ Lipofectamine 2000, 
Table IV. NGF-shRNA primer pairs.

Primer name

Sequences $\left(5^{\prime}-3^{\prime}\right)$

\section{NGF-shRNA1-F \\ NGF-shRNA1-R \\ NGF-shRNA2-F \\ NGF-shRNA2-R \\ NGF-shRNA3-F \\ NGF-shRNA3-R \\ NGF-shRNAs-F \\ NGF-shRNAs-R \\ q-NGF-F \\ q-NGF-R}

GAPDH-F

GAPDH-R

\begin{abstract}
CCGGGCAGACCCGCAACATTACTGTCTCGAGACAGTAATGTTGCGGGTCTGCTTTTTG AATTCAAAAAGCAGACCCGCAACATTACTGTCTCGAGACAGTAATGTTGCGGGTCTGC CCGGGAGAGGTGAACATTAACAACACTCGAGTGTTGTTAATGTTCACCTCTCTTTTTG AATTCAAAAAGAGAGGTGAACATTAACAACACTCGAGTGTTGTTAATGTTCACCTCTC CCGGGGGATATGGTACAACCCTTGTCTCGAGACAAGGGTTGTACCATATCCCTTTTTG AATTCAAAAAGCATTGACTCAAAGCACTGGACTCGAGTCCAGTGCTTTGAGTCAATGC CCGGGGGATATGGTACACCGCGGTTTATCCGGATAGATACCTCGAGGTATCTATCCGG AATTCAAAAAGCATTAAAAGCGGTTTATCCGGATAGATACCTCGAGGTATCTATCCGG GGCAGACCCGCAACATTACT CACCACCGACCTCGAAGTC AGGTGAAGGTCGGAGTCA GGTCATTGATGGCAACAA
\end{abstract}

F, forward; R, reverse; NGF, nerve growth factor; shRNA, short hairpin RNA. ${ }^{\text {a }}$ shRNAs refers to negative control.

along with empty lentiviral vectors as a control. After a 72-h incubation at $37^{\circ} \mathrm{C}$, the supernatants were collected, filter sterilized and further used to infect the breast cancer cell lines MDA-MB231 and T-47D (twice, every 24 h; MOI, 8). A total of $48 \mathrm{~h}$ post-infection, the infected cells were used to select target cells by puromycin selection as aforementioned.

MDA-MB231-pLKO-NGF-shRNA1/3, T-47D-pLKONGF-shRNA1/3, MDA-MB231-pLKO-shRNA (negative control), T-47D-pLKO-shRNA (negative control) and MDA-MB231 or T-47D cells were seeded onto $60-\mathrm{mm}$ culture plates $\left(2.5 \times 10^{5}\right.$ cells in $5 \mathrm{ml}$ DMEM) in triplicate. After 72 h, total cell RNA was collected for NGF qPCR, as aforementioned, using the following cycling conditions: Initial denaturation at $95^{\circ} \mathrm{C}$ for $5 \mathrm{~min}$; followed by 35 cycles of $95^{\circ} \mathrm{C}$ for $30 \mathrm{sec}, 50^{\circ} \mathrm{C}$ for $60 \mathrm{sec}$ and $72^{\circ} \mathrm{C}$ for $60 \mathrm{sec}$; and a final extension at $95^{\circ} \mathrm{C}$ for $5 \mathrm{sec}$. The GAPDH was used as the internal reference.

Detection of cell viability in breast cancer cells containing different recombinant plasmids. Cell viability of MDA-MB231-pCDH-NGF-FLAG (overexpression group), MDA-MB231 (untreated group), MDA-MB231-pLKO-NGF-shRNA1 (silent group) and MDA-MB231-E3-A (knockout group) was determined by MTT assays. Cells were seeded $\left(2.5 \times 10^{4}\right.$ cells $/ \mathrm{ml} ; 4,000$ cells $/$ well $)$ onto 96-microwell plates in triplicate. After 24, 48, 72 and $96 \mathrm{~h}$ at $37^{\circ} \mathrm{C}$, cells were collected for MTT assay. Briefly, MTT (200 $\mu \mathrm{g} / \mathrm{ml}$; prepared in serum-free DMEM) was added to the wells, and the cells were incubated at $37^{\circ} \mathrm{C}$ for $4 \mathrm{~h}$. The supernatants were removed, and $150 \mu$ l dimethyl sulfoxide was added to each well to dissolve the purple formazan crystals. After shaking for $15 \mathrm{~min}$ at room temperature, the optical density was detected at $490 \mathrm{~nm}$ using a Multiskan Spectrum microplate spectrophotometer (Thermo Fisher Scientific, Inc.). Experiments were repeated three times.

Influence of NGF on PC12 cellneuronal differentiation activity. PC-12 is a classic neuronal cell line. Studies have suggested that NGF can induce PC-12 cell differentiation (26-28). Thus, undifferentiated PC12 cells (The Cell Bank of Type Culture Collection of the Chinese Academy of Sciences) were cultured in RPMI-1640 medium (cat. no. SH30809.018; Hyclone; Cytiva) supplemented with $10 \%$ horse serum (cat. no. 26050088; Gibco; Thermo Fisher Scientific, Inc.) and 5\% FBS, and were treated with 10,50 and $100 \mathrm{ng} / \mathrm{ml}$ NGF cell supernatants from NGF-overexpressing MDA-MB231 cells at $37^{\circ} \mathrm{C}$. NGF was obtained from the supernatants of NGF-overexpressing cells and the concentrations were confirmed by ELISA (Human NGF/NGF- $\beta$ ELISA kit; cat. no. EK0469; Boster Biological Technology). NGF- $\beta$ standards was used to establish the standard curve. The cell number and axon length were calculated by fluorescence microscopy (NIKON Ti-s inverted fluorescence microscope; Nikon Corporation); 250 cells from five fields of vision $(n=50)$ were analyzed.

Statistical analysis. All data are presented as the mean \pm standard deviation. Statistical analysis was assessed by Kruskal-Wallis followed by Dunn's post hoc test for multiple comparison test; Student's t-test was used to compare two groups. Clinicopathological characteristics were compared by $\chi^{2} . \mathrm{P}<0.05$ was considered to indicate a statistically significant difference.

\section{Results}

Association between PGP9.5 expression level and clinicopathological features of breast cancer. The 92 clinical specimens of breast cancer were collected and classified according to the age of the patients, tumor size and histological grade (Table I; Table SI); the tissue samples were used to examine PGP9.5 expression by immunohistochemical analysis (Fig. S1); PGP9.5 was used as a neuronal marker. The results showed that the positive expression rate of PGP9.5 was not associated with the age or tumor size of patients with breast cancer (both $\mathrm{P}>0.05$ ), whereas it was positively related with the pathological grade of breast cancer $(\mathrm{P}<0.05)$. 

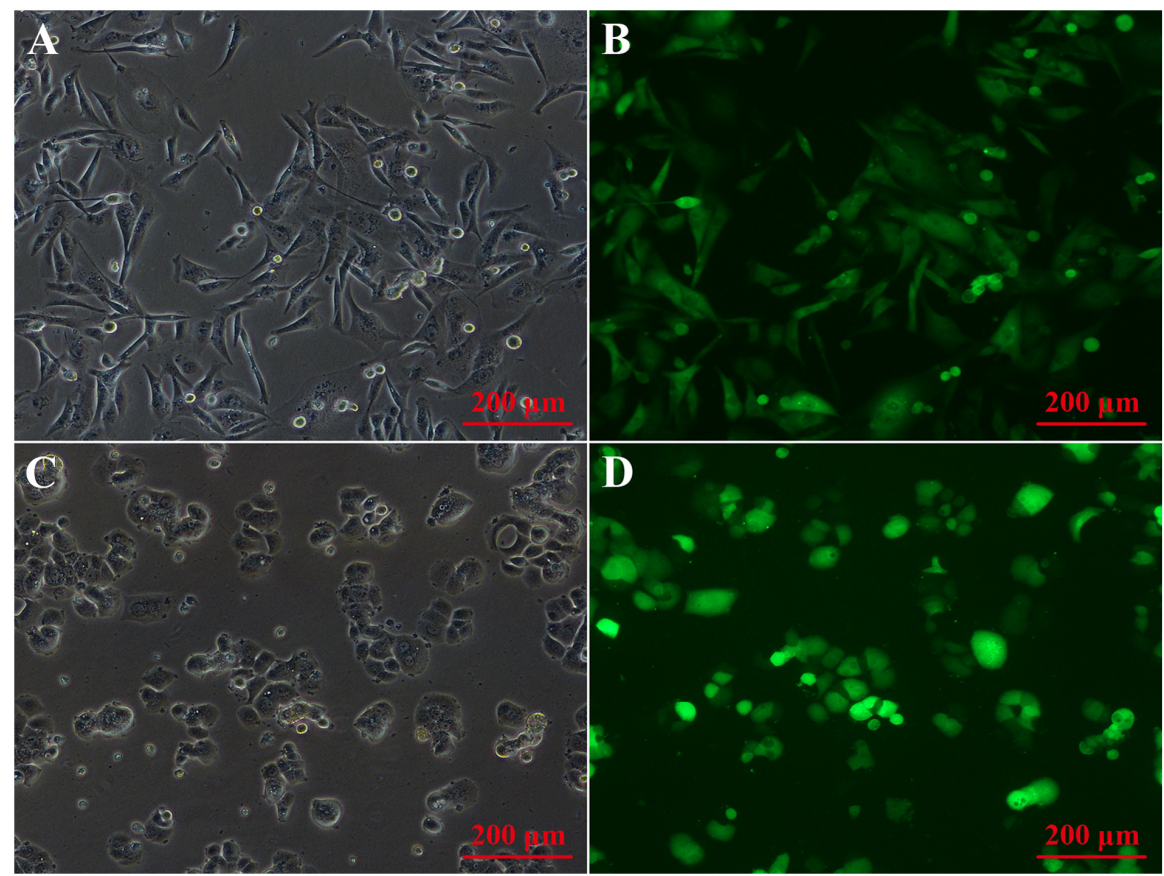

Figure 1. Bright field and fluorescence microscopy were used to observe the infection efficiency of nerve growth factor lentiviral overexpression vector in breast cancer cells. (A) White light and (B) fluorescence imaging of MDA-MB231 cells; magnification, x10. (C) White light and (D) fluorescence imaging of T-47D cells; magnification, $\mathrm{x} 10$.
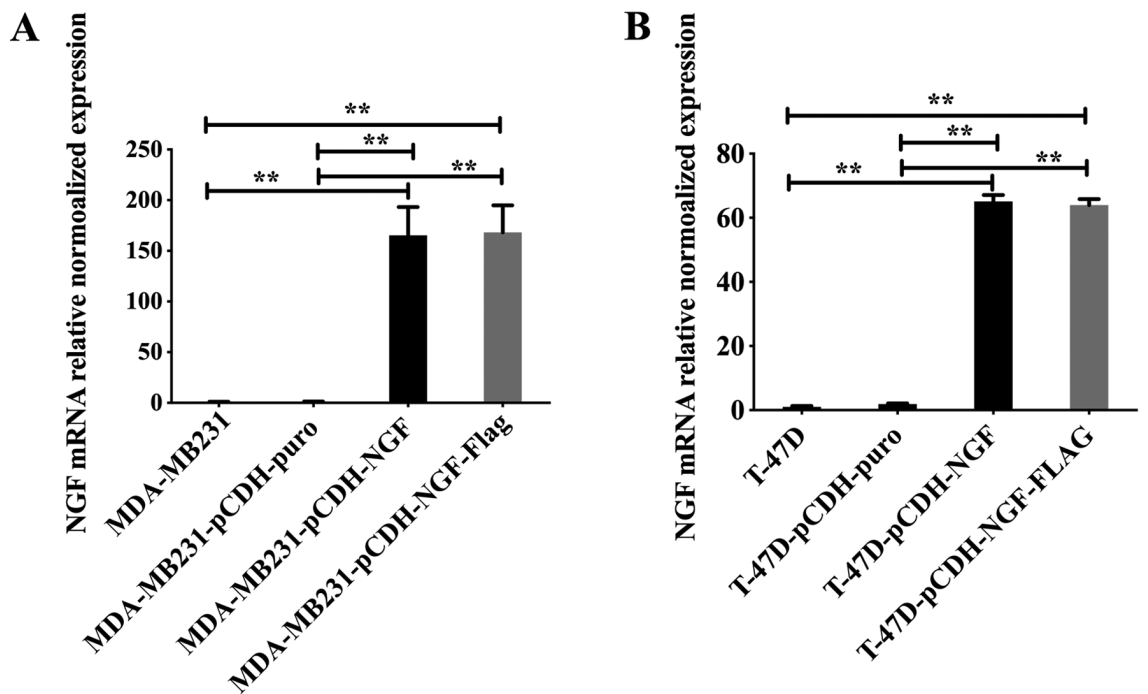

Figure 2. NGF mRNA expression levels in lentiviral NGF overexpression vector-infected breast cancer cells. (A) MDA-MB-231 cell line. (B) T-47D cell line. Overexpression groups, MDA-MB-231-pCHD-NGF-FLAG and T-47D-pCDH-NGF-FLAG; untransfected cells groups, MDA-MB-231 and T-47D cells; pCDH-puro groups, MDA-MB-231-pCHD-NGF-puro and T-47D-pCDH-NGF-puro. Data are presented as the mean \pm SD of three independent experiments. ${ }^{* *} \mathrm{P}<0.01$. NGF, nerve growth factor; puro, puromycin.

Construction of recombinant NGF lentiviral overexpression plasmids. Genomic DNA from MDA-MB231 and T-47D breast cancer cells was extracted and used to construct recombinant pMD18-T-NGF plasmids, which were verified by PCR and sequencing, and used as a template to construct NGF-FLAG using primers containing FLAG sequences and $\mathrm{XbaI} / \mathrm{BamHI}$ enzyme loci. The double-enzyme digested product was further linked to the vector pCDH-CMV-MCS-EF1-puro to construct a recombinant NGF lentiviral overexpression plasmid; the infection efficiency was verified by fluorescence microscopy. Bright field and fluorescence microscopy were used to observe the infection efficiency of NGF lentiviral overexpression vector in breast cancer cells, and the results showed that NGF lentiviral overexpression plasmids could efficiently infect breast cancer cells (Fig. 1).

The puromycin-screened breast cancer cells, including the overexpression (pCDH-NGF and pCDH-NGF-FLAG), vector (pCDH-puro) and untransfected (MDA-MB231 and T-47D cells) groups, were collected and NGF mRNA expression levels were examined by qPCR (Fig. 2). The results showed that NGF mRNA expression levels in the overexpression groups were significantly higher compared with those in the 


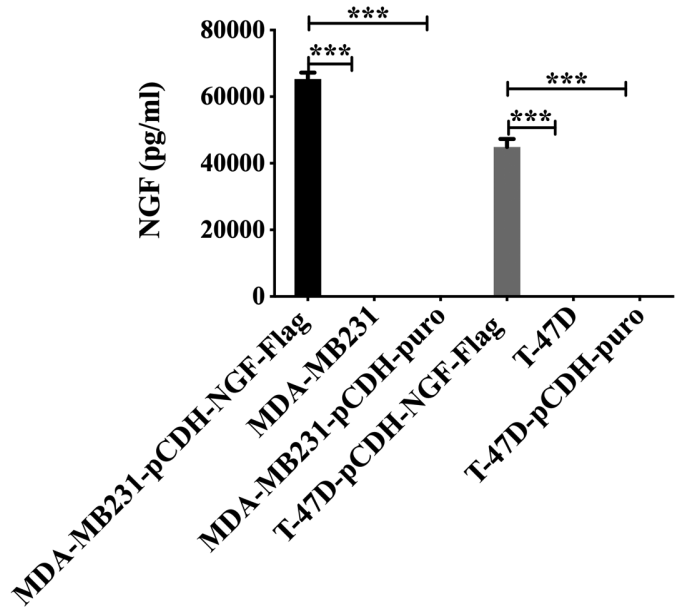

Figure 3. Concentration of NGF- $\beta$ in the supernatant of lentiviral NGF overexpression vector-infected breast cancer cells. Overexpression groups, MDA-MB231-pCHD-NGF-FLAG and T-47D-pCDH-NGF-FLAG; untreated cells, MDA-MB231 and T-47D; vector control groups, MDA-MB231-pCHD-NGF-puro and T-47D-pCDH-NGF-puro. Data are presented as the mean $\pm \mathrm{SD}$ of three independent experiments. ${ }^{* * *} \mathrm{P}<0.001$. NGF, nerve growth factor; puro, puromycin.

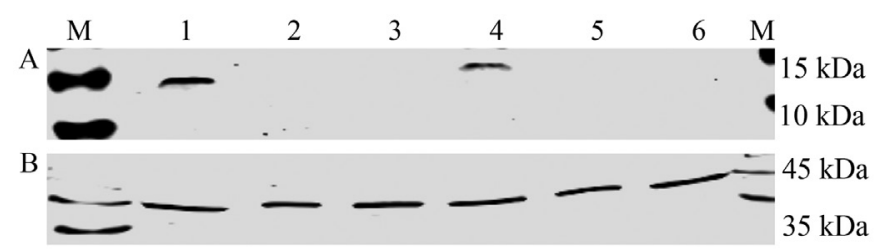

Figure 4. NGF protein expression levels in NGF lentiviral overexpression vector-infected breast cancer cells using anti-FLAG antibody. (A) Upper row, 1, MDA-MB231-pCDH-NGF-FLAG; 2, MDA-MB231-pCDH-puro 3, MDA-MB231; 4, T-47D-pCDH-NGF-FLAG; 5, T-47D-pCDH-puro; 6, T-47D. Overexpression groups, MDA-MB231-pCHD-NGF-FLAG and T-47D-pCDH-NGF-FLAG; untransfected cells groups, MDA-MB231 and T-47D; pCDH-puro groups, MDA-MB-231-pCHD-NGF-puro and T-47D-pCDH-NGF-puro. (B) Lower row, $\beta$-actin was used as internal reference. M, marker; NGF, nerve growth factor; puro, puromycin.

untransfected and pCDH-puro groups $(\mathrm{P}<0.01)$, whereas there was no statistically significant difference between the untransfected and pCDH-puro groups ( $\mathrm{P}>0.05$ ) (Fig. 2), suggesting the successful construction and infection of recombinant NGF lentiviral overexpression plasmids.

Levels of NGF in breast cancer cells transfected with overexpression plasmid. The cell supernatants from the untransfected (MDA-MB-231 and T-47D), vector (MDAMB231-pCHD-NGF-puro and T-47D-pCDH-NGF-puro) and overexpression (MDA-MB231-pCHD-NGF-FLAG and T-47D-pCDH-NGF-FLAG) groups were collected and analyzed by NGF- $\beta$ ELISA. The results showed that the levels of NGF- $\beta$ in the overexpression groups were significantly higher than those in the untransfected and $\mathrm{pCDH}$-puro groups $(\mathrm{P}<0.001)$, whereas the levels of NGF- $\beta$ showed no statistically significant difference between the untransfected and pCDH-puro groups (P>0.05) (Fig. 3).

The cell supernatants from the untransfected (MDA-MB231 and T-47D), overexpression (MDA-MB231-pCHD-NGF-
FLAG and T-47D-pCDH-NGF-FLAG) and vector (MDAMB231-pCHD-NGF-puro and T-47D-pCDH-NGF-puro) groups were concentrated by ultrafiltration centrifuge tubes, and $\beta$-actin (42.0 $\mathrm{kDa}$; lower row) was used as the internal reference. The results showed that NGF overexpression breast cancer cell lines could secrete mature NGF protein (NGF, $13.5 \mathrm{kDa}$; FLAG, $1 \mathrm{kDa}$; FLAG binds to NGF, the total size is $14.5 \mathrm{kDa}$; upper row), whose expression levels were markedly higher than those of the vector and untransfected groups (Fig. 4).

Together, these results demonstrated that MDA-MB231pCHD-NGF-FLAG and T-47D-pCDH-NGF-FLAG-infected breast cancer cells contained NGF overexpression plasmids.

Construction of recombinant NGF lentiviral knockout plasmids. The results showed that NGF lentiviral knockout plasmids could efficiently infect MDA-MB231 and T-47D breast cancer cells (Fig. 5).

Flow cytometry was used to sort individual CRISPR/Cas9-edited cells, which were subsequently verified by PCR and agarose gel electrophoresis (Fig. S2; 726 bp), and the PCR identified-cells were used for further sequencing (Fig. 6). After repetition of the described analysis three times, the genotype of the breast cancer cell could be confirmed. As shown in Fig. 7, MDA-MB231-E3-A was a homozygous (biallelic) knockout cell line, whereas MDA-MB231-E3-B was heterozygous (monoallelic) knockout cell line.

Puromycin-screened breast cancer cells were collected, including the knockout (MDA-MB231-E3-A and -E3-B) and untreated cells (MDA-MB231) groups, and their RNA was extracted and used for RT-qPCR analysis. The results showed that the NGF mRNA expression levels in the knockout groups were significantly lower compared with those in the normal group $(\mathrm{P}<0.01$; Fig. 8), suggesting the successful construction and infection of recombinant NGF lentiviral knockout plasmids.

Construction of recombinant shRNA-NGF lentiviral plasmids. The designed NGF-shRNA1/2/3s and negative control shRNA were designed and inserted into the lentiviral vector $\mathrm{pLKO} .1$ using the primers listed in Table III. pLKO-NGF-shRNA1/2/3 and control shRNA were verified by ampicillin-resistant assay, double enzyme digestion assay and sequenced. The results showed that shRNA2 failed to knockdown NGF, thus only shRNA1 and 3 were used in subsequent experiments.

Puromycin-screened breast cancer cells, including the silenced (MDA-MB-231-NGF-shRNA1 and -shRNA3, and T-47D-NGF-shRNA1 and -shRNA3), negative control (MDA-MB231-pLKO-shRNA and T-47D-pLKO-shRNA) and untreated (MDA-MB231 and T-47D) groups, were examined by qPCR. The results showed that NGF mRNA expression levels in the MDA-MB231-NGF-shRNA1, T-47D-NGF-shRNA1 and MDA-MB231-NGF-shRNA3 groups were significantly lower compared with those in the untreated cells and negative control groups $(\mathrm{P}<0.05)$; whereas no statistically significant differences were identified when T-47D-NGF-shRNA3 was compared with untreated and negative control groups $(\mathrm{P}>0.05)$ (Fig. 9), which suggested the successful construction and infection of the recombinant shRNA-NGF lentiviral plasmids MDA-MB231-NGF-shRNA1 and T-47D-NGF-shRNA1. 


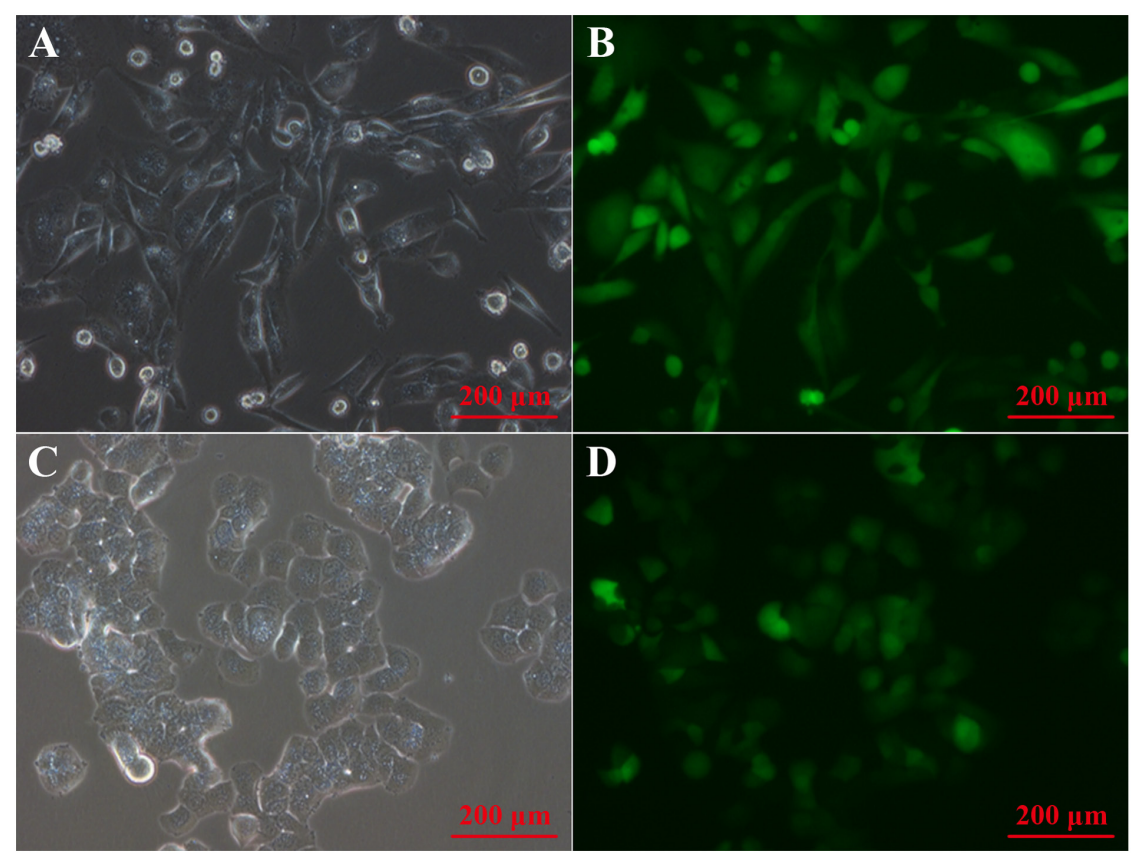

Figure 5. Brightfield and fluorescence microscopy was used to observe the infectious efficiency of NGF lentiviral knockout plasmids in breast cancer cells. (A) White light and (B) fluorescence imaging of MDA-MB-231 cells (MDA-MB231-LentiCRISPRv2-NGF-gRNA2), magnification, x20. (C) White light and (D) fluorescence imaging of T-47D cells (T-47D-LentiCRISPRv2-NGF-gRNA2), magnification, x20.

CLUSTAL 0(1.2.4) multiple sequence alignment

$\begin{array}{llr}\text { NGF } & \text { ATGTCCATGTTGTTCTACACTCTGATCACAGCTTTTCTGATCGGCATACAGGCGGACCA } & 60 \\ \text { NGF_edit } & \text { ATGTCCATGTTGTTCTACACTCTGATCACAGCTTTCTGATC-----GGCGACCA } & 52 \\ & * * * * * * * * * * * * * * * * * * * * * * * * * * * * * * * * * * * * * * & \\ \text { NGF } & \text { CACTCAGAGAGCAATGTCCCTGCAGGACACACCATCCCCCAAGCCCACTGGACTAAACTT } & 120 \\ \text { NGF_edit } & \text { CACTCAGAGAGCAATGTCCCTGCAGGACACACCATCCCCCAAGCCACTGGACTAAACTT } & 112 \\ & * * * * * * * * * * * * * * * * * * * * * * * * * * * * * * * * * * * * * * * * * * * * * * * * * * * * * * * * & \\ \text { NGF } & \text { CAGCATTCCCTTGACACTGCCCTTCGCAGAGCCCGCAGCGCCCCGGCAGCGGCGATAGCT } & 180 \\ \text { NGF_edit } & \text { CAGCATTCCCTTGACACTGCCCTTCGCAGAGCCCGAGCGCCCGGCAGCGGCATAGCT } & 172 \\ & * * * * * * * * * * * * * * * * * * * * * * * * * * * * * * * * * * * * * * * * * * * * * * * * * * * * * * * & \end{array}$

Figure 6. The CRISPR/Cas9-edited cells were verified through sequencing. Flow cytometry was used to sort the CRISPR/Cas9-edited cells, which were verified by sequencing. Upper sequence, wild type; lower sequence, NGF CRISPR/Cas9 knockout cell (deletion mutation). Asterisks $(*)$ refer to where the wild-type and CRISPR/Cas9 knockout cell sequences share an identical base; horizontal bars (-) refer to where the wild-type and CRISPR/Cas9 knockout cell sequences have different bases.

A MDA-MB231-E3-A:Mutations in 15 sequenced clones atcacagcttttctgatcggca tacaggcge ATCACAGCTTTTCTGATCGgCAATACAGGCGG ATCACAGCTTTTCTGATCGgCATACAgGCGg.

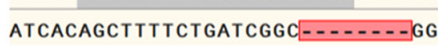
ATCACAGCTtTTCtGATCGgCATACAGgCGgaAC. ATCACAGCTTTTCTGA-.................... In/Del Freq $+1 \quad 2 x$ $-8 \quad 7 x$ $-17 \quad 6 x$
B MDA-MB231-E3-B:Mutations in 15 sequenced clones In/Del Freq

\begin{tabular}{|c|c|}
\hline $\begin{array}{l}\text { CACAGCTITTCTGATCGGCATACAGGCGGAACCACACTCAGAG } \\
\text { CACAGCTTITCTGATCGGCATACAGGCGGAACCACACTCAGAG. } \\
\text { CACAGCTITTCTGTCGGA TACAGGCGGACCACACTCAGAGAG }\end{array}$ & 0 \\
\hline $\begin{array}{l}\text { CACAGCTITTCTGATCGGCAQATACAGGCGGAACCACACTCAGAGAG } \\
\text { CACAGCTTITTGATCGGCATACAGGGGGAACCACACTCAGAGAG }\end{array}$ & +1 \\
\hline $\begin{array}{l}\text { CACAGCITITCTGATCGGC........GGAACAACACTCAGAGAG } \\
\text { CACAGCTITTCTGATCGGCATACAGGGGGACCACACTCAGAGA }\end{array}$ & \\
\hline
\end{tabular}

Figure 7. Genotypes of two MDA-MB231-CRISPR/Cas9 edited cells. (A-B) The open-reading frame of NGF was sequenced. The upper row refers to the wild-type NGF sequence, and the lower row refers to the sequencing report of the alignment sequence. The red bar represents the base deletion. By comparing each sequence with the wild-type sequence, what changes (the base insertion or deletion, or no change) have taken place in the genome of CRISPR/Cas9 edited single cell could be confirmed. MDA-MB231-E3-A was a homozygote cell line (biallelic knockout cell), whereas MDA-MB231-E3-B was a heterozygote cell line (monoallelic knockout cell). Freq, frequency; In/Del, insertion deletion.

Levels of NGF in knockout and knockdown MDA-MB231 breast cancer cells. Culture supernatants from the knockout (MDA-MB231-E3-A and -E3-B), silenced (MDA-MB231-pLKO-NGF-shRNA1), negative control 
Table V. Influence of NGF on the formation of PC12 cell protrusion ( $n=50$, cell numbers).

\begin{tabular}{lccc}
\hline Group & Number of protrusions & Maximum diameter $(\mu \mathrm{m})$ & Longest protrusion length $(\mu$ m) \\
\hline Control & 0.6 & 6.5 & 2.5 \\
NGF $(10 \mathrm{ng} / \mathrm{ml})$ & $3.0^{\mathrm{a}}$ & 7.9 & $5.1^{\mathrm{a}}$ \\
NGF $(50 \mathrm{ng} / \mathrm{ml})$ & $3.52^{\mathrm{a}}$ & $9.3^{\mathrm{a}}$ & $8.16^{\mathrm{a}}$ \\
NGF $(100 \mathrm{ng} / \mathrm{ml})$ & $3.8^{\mathrm{a}}$ & $11.2^{\mathrm{a}}$ & $13.54^{\mathrm{a}}$ \\
\hline
\end{tabular}

NGF, nerve growth factor. ${ }^{\text {arefers }}$ to significance $(\mathrm{P}<0.05)$ when compared with control.

$\mathbf{A}$
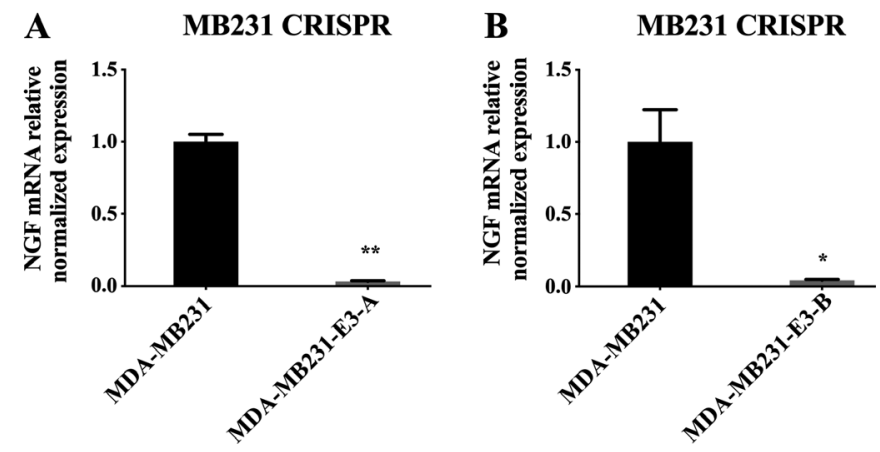

Figure 8. Relative NGF mRNA expression levels in NGF lentiviral knockout MDA-MB231 breast cancer cells. (A) Homozygous (biallelic) knockout cell (MDA-MB231-E3-A). (B) Heterozygous (monoallelic) knockout cell (MDA-MB231-E3-B). Knockout groups (MDA-MB-231-E3-A and -E3-B) and control group (MDA-MB231). Data are presented as the mean \pm SD of 3 independent experiments. ${ }^{*} \mathrm{P}<0.05$, vs. MDA-MB231. NGF, nerve growth factor.
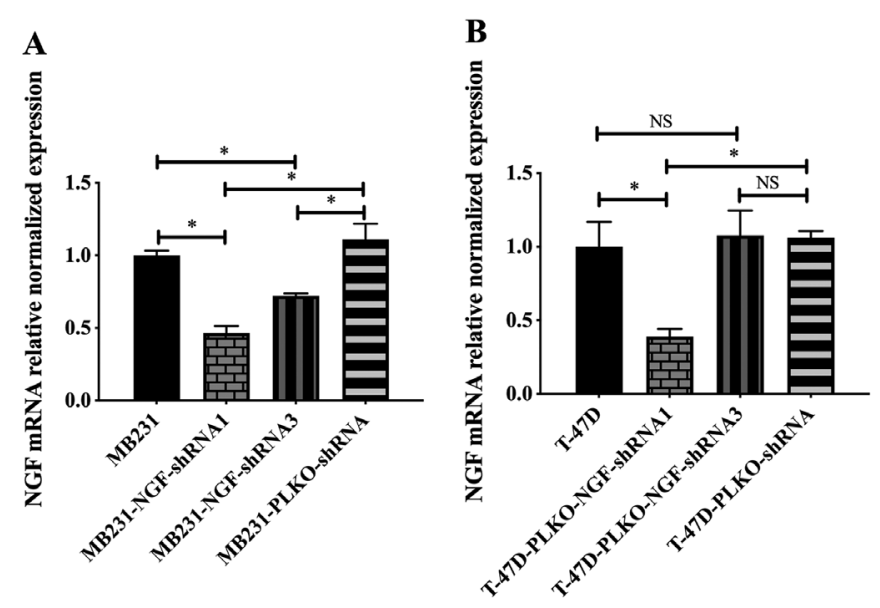

Figure 9. Relative NGF mRNA expression levels in shRNA-NGF lentiviral silenced breast cancer cells. (A) MDA-MB231 cell line. (B) T-47D cell line. Silenced groups, MDA-MB231-NGF-shRNA1 and -shRNA3 and T-47D-NGF-shRNA1 and -shRNA3; untransfected groups, MDA-MB231 and T-47D; negative control groups, MDA-MB231-pLKO-shRNA and T-47D-pLKO-shRNA. The silenced groups were compared with untransfected and negative control groups. Data are presented as the mean \pm SD of three independent experiments. ${ }^{*} \mathrm{P}<0.05$. NGF, nerve growth factor; shRNA, short hairpin RNA.

(MDA-MB231-pLKO-shRNA) and untreated (MDA-MB231) groups were collected and analyzed using an NGF- $\beta$ ELISA

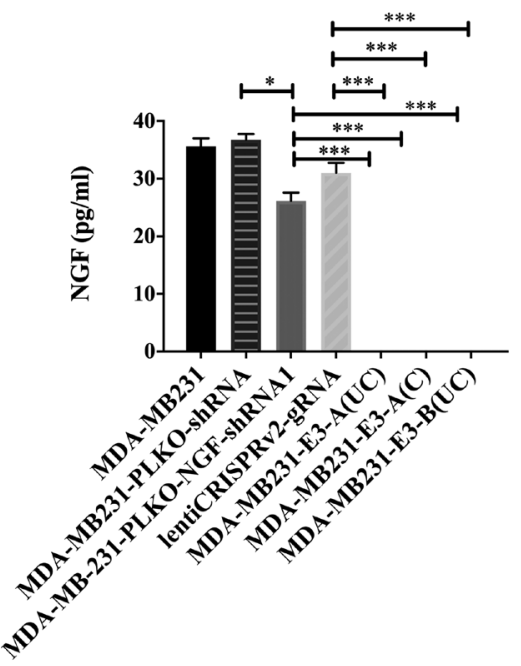

Figure 10. Concentration of NGF- $\beta$ in the supernatant of NGF lentiviral knockout and silenced breast cancer cells. Knockout groups, MDA-MB231-E3-A and MDA-MB231-E3-B; knockout negative group, lentiCRISPRv2-NGF-gRNA; silent group, MDA-MB231-pLKO-NGF-shRNA1; silent negative group, MDA-MB231-pLKO-NGF-shRNA; normal group, MDA-MB231. Data are presented as the mean \pm SD of three independent experiments. ${ }^{*} \mathrm{P}<0.05,{ }^{* * * *} \mathrm{P}<0.001$. NGF, nerve growth factor; shRNA, short hairpin RNA; gRNA, guide RNA.

kit. The results showed that the levels of NGF- $\beta$ in the knockout and shRNA groups were significantly lower than those in the negative control groups $(\mathrm{P}<0.05)$, whereas the levels of NGF- $\beta$ in the knockout groups were lower than those in the shRNA silenced group $(\mathrm{P}<0.001)$ (Fig. 10).

Detection of cell viability in breast cancer cells transfected with the different recombinant plasmids. The overexpression (MDA-MB231-pCDH-NGF-FLAG), knockout (MDA-M B231-E3-A), silenced (MDA-MB231-pLKO-NGF-shRNA1), negative control (MDA-MB231-pCDH-NGF-puro, lentiCRISPRv-NGF-gRNA and MDA-MB231-pLKO-NGF-shRNA) and untreated (MDA-MB231) groups were used to examine the effects on the viability of breast cancer cells transfected with different recombinant plasmids. The results showed that the viability of cells in the NGF overexpression group was significantly higher compared with the negative control group at 24, 48, 72 and $96 \mathrm{~h}(\mathrm{P}<0.05)$, whereas the viability of the NGF knockout and silenced groups was lower than that of the negative control groups at 24 or $48 \mathrm{~h}(\mathrm{P}<0.05)$ and showed no statistically significant difference at 72 or $96 \mathrm{~h}$ (Fig. 11). 

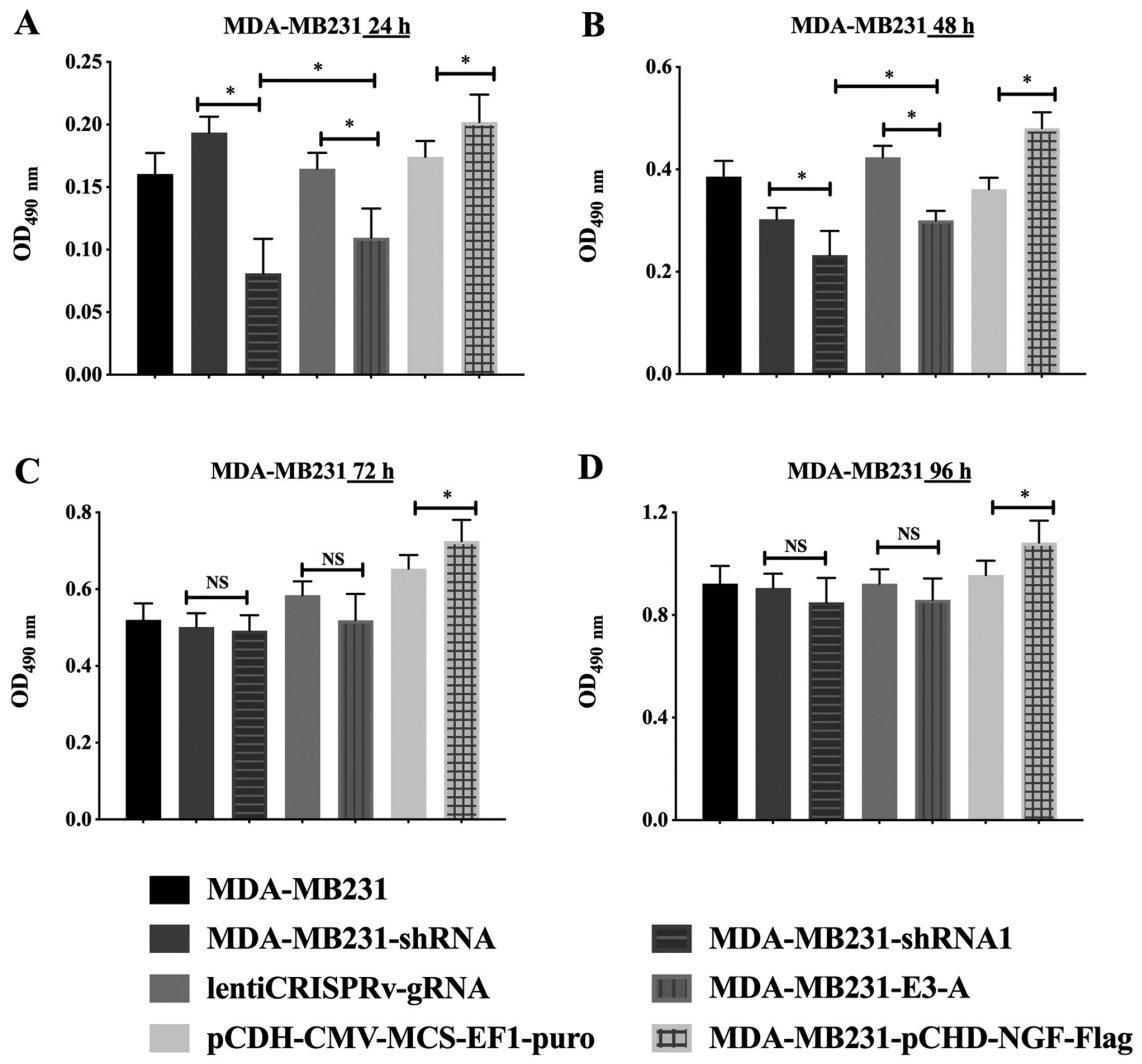

Figure 11. Detection of breast cancer cell viability in cells with different recombinant plasmids. Overexpression group, MDA-MB231-pCDH-NGF-FLAG; overexpression negative group, MDA-MB231-pCDH-NGF-puro; knockout group, MDA-MB231-E3-A; knockout negative group, lentiCRISPRv-NGF-gRNA; silent group, MDA-MB231-pLKO-NGF-shRNA1; silent negative group, MDA-MB231-pLKO-NGF-shRNA; normal group, MDA-MB231. The effects on the viability of breast cancer cells transfected with different recombinant plasmids at (A) 24, (B) 48, (C) 72 and (D) $96 \mathrm{~h}$ were detected. Data are presented as the mean \pm SD of three independent experiments. "P<0.05. NGF, nerve growth factor; shRNA, short hairpin RNA; gRNA, guide RNA; puro, puromycin; OD, optical density.

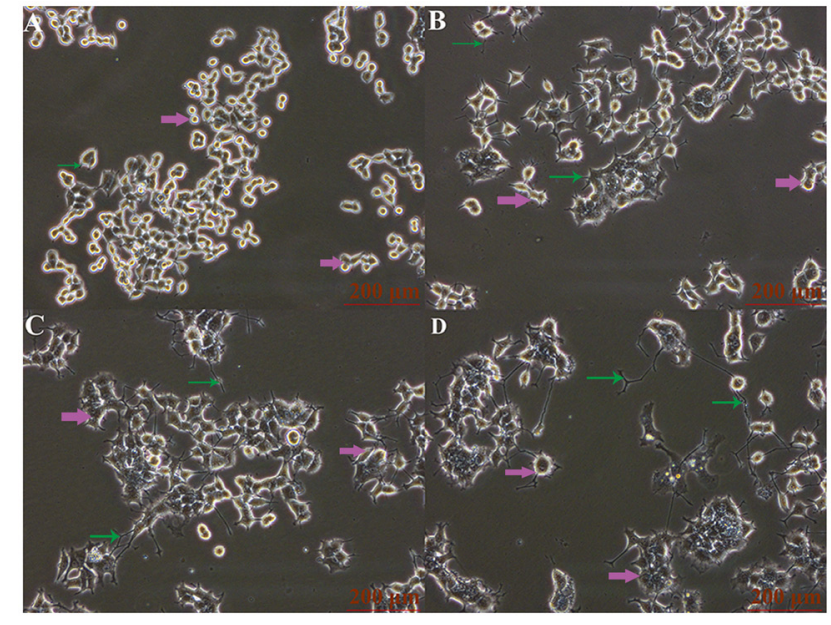

Figure 12. Morphological features of PC12 cells treated with different concentrations of NGF for $96 \mathrm{~h}$. (A) Untreated cells. (B) $10 \mathrm{ng} / \mathrm{ml} \mathrm{NGF}$. (C) $50 \mathrm{ng} / \mathrm{ml} \mathrm{NGF}$. (D) $100 \mathrm{ng} / \mathrm{ml}$ NGF. The number of protrusions, the length of protrusions and the size of the PC12 cells can be seen. Green arrows refer to protrusions; pink arrows refer to PC12 cells. NGF, nerve growth factor.

Influence of NGF on neuronal differentiation activity of PC12 cells. The classic neuronal cell line, PC12, was cultured and treated with cell supernatants containing 10,50 and $100 \mathrm{ng} / \mathrm{ml}$ NGF from NGF-overexpressing MDA-MB231 cells. The results showed that the maximum protrusion length, and the number of protrusions and the maximum diameter of cells were increased with the increasing NGF concentrations (Fig. 12; Table V), which suggested that PC12 cells could be altered by NGF in a concentration-dependent manner.

\section{Discussion}

Nerve fibers, like blood vessels and lymphatics, are spread throughout the body. Numerous studies have reported that cancer angiogenesis and lymphangiogenesis occur in the cancer microenvironment (29-32), but the potential biological effects of cancer-related neurogenesis have been rarely reported. Tumor cells can use a large number of factors secreted by nerve fibers to create microenvironments to help them survive and proliferate, such as epinephrine, catecholamines and adrenaline (7,33-38). At the same time, tumor cells can stimulate the production of neurons by secreting neurotrophic factors and axonal guiding molecules (11). The interaction between tumor cells and their microenvironment promotes tumor development (39). In general, if the tumor is diagnosed early, surgical resection of the primary lesion can be used for an effective cure. Tumor cells can invade surrounding tissues and develop into invasive diseases, leading to severe consequences. The majority of cancer-related deaths are closely associated with the formation of invasive tumor tissues. Numerous cytokines and soluble components, such as IL-1 1, IL-6, IL-17 and IL-32 in the tumor microenvironment affect tumorigenesis, and the 
microenvironment is continually changing according to the evolution of the tumor. Recruitment of a variety of cytokines to the surrounding environment can help to form the secretory environment of soluble factors, and also assist in the regeneration of blood vessels and the lymphatic system (40-47).

In the early $1970 \mathrm{~s}$, Folkman et al (48) first discovered the tumor angiogenesis ability. Since then, numerous studies have attempted to determine the mechanism of angiogenesis and develop corresponding treatments $(49,50)$. Angiogenesis markedly affects the development of the tumor and is involved in the development of in situ invasive tumors. Vascular endothelial growth factor (VEGF) A and its receptor 2 (VEGFR2; also known as FLK1) play an important role in it (51). Currently, treatments based on VEGF can effectively improve the survival time of patients with a malignant tumor, but only for a few months (52). Lymphangiogenesis is an important cause of tumor cell invasion (53). Previous studies have shown that lymphangiogenic factors affect the proliferation of tumor cells, and the specific marker of lymphatic angiogenesis is LYVE-1 (54-58). In addition, VEGF-c and VEGF-d play a role in lymph node metastasis in multiple human tumor cells, which demonstrates the importance of this factor in tumor metastasis $(54,58,59)$.

Similar to angiogenesis and lymphangiogenesis, neurogenesis also occurs in tumor cells. Although previous studies have demonstrated that bladder $(59,60)$, prostate $(61)$, breast $(62)$ and pancreas (63) cancers contain nerve endings, only in prostate cancer have newborn axons been identified (64). Numerous studies have shown that neuropeptides and neurotransmitters in the tumor microenvironment affect neurogenesis (61-64).

Early studies suggested that nerve fibers guide the migration of the invading nerve cells (63). Other studies have found that the nervous system regulates numerous secreted molecules associated with the development of tumors. For example, neurotransmitters are associated with the immune suppression of tumors and induce changes in angiogenesis and vascular density (65-67). The presence of neurons in the tumor tends to lead to a poor prognosis (68). Besides, the nervous system and the tumor are mutually beneficial, since tumor cells can secrete nerve molecules (69-71) and axonal guide molecules (72) to stimulate the nerve endings to penetrate the tumor.

Previous data showed that NGF serves crucial regulatory roles in the development, differentiation, growth and regeneration of neurons (73). In the present study, 92 clinical cases of breast cancer were collected, and the presence of neurons in the breast cancer microenvironment was verified by immunohistochemistry. To explore the role of NGF in cancer-related neurogenesis, recombinant NGF lentiviral overexpression, knockout and silencing plasmids were constructed. Furthermore, whether NGF affected neuron growth was preliminary confirmed, and the results showed that the maximum length, and number of protrusions and maximum diameter were increased with the increase in NGF concentration.

For further direction, since previous studies reported that as a classical tumor angiogenesis regulatory factor, VEGF also plays a role similar to neurotrophic factor and axon guidance factor, and is involved in the processes of axon growth, neuronal cell migration, axon guidance and neural connection $(51,74)$. VEGF not only affects the growth of primary cortical neurons as a neurotrophic factor, but also stimulates the growth of axons and neurons in dorsal root ganglia and regulates the migration of neural crest cells and astrocytoma cells $(51,75,76)$. However, whether it is involved in cancer-related neurogenesis remains unknown. Multiple differential expression plasmids of VEGF will be constructed to detect if it is a downstream target of NGF. Since there are few studies regarding the role of NGF in cancer-associated neurogenesis and cancer-related axonogenesis $(2,7,9,11)$, the differential expression plasmids constructed in the present study may provide an important basis for further studies to elucidate its role in this phenomenon.

\section{Acknowledgements}

The authors would like to thank Mr. Ding Zhang (The First College of Clinical Medical Science, China Three Gorges University; Yichang, China) for providing the patients' breast cancer samples.

\section{Funding}

Financial support for this project was provided by the Hubei Office of Education Foundation (grant no. Q20151204)

\section{Availability of data and materials}

The datasets used and/or analyzed during the current study are available from the corresponding author on reasonable request.

\section{Authors' contributions}

YL, PW, JZ and CY performed the experiments. JW conceived the project and analyzed the results. LZ drafted the manuscript and analyzed the results. All authors read and approved the final manuscript.

\section{Ethics approval and consent to participate}

Approval was received from the Ethics Committee of The First College of Clinical Medical Science, China Three Gorges University (Yichang, China), and written consent from patients were obtained prior to using the breast tissues for research related activities, including paper publication.

\section{Patient consent for publication}

Not applicable.

\section{Competing interests}

The authors declare that they have no competing interest.

\section{References}

1. Hutchings C, Phillips JA and Djamgoz MBA: Nerve input to tumours: Pathophysiological consequences of a dynamic relationship. Biochim Biophys Acta Rev Cancer 1874: 188411, 2020.

2. Cervantes-Villagrana RD, Albores-Garcia D, Cervantes-Villagrana AR and García-Acevez SJ: Tumor-induced neurogenesis and immune evasion as targets of innovative anti-cancer therapies. Signal Transduct Target Ther 5: 99, 2020. 
3. Jiang SH, Hu LP, Wang X, Li J and Zhang ZG: Neurotransmitters: Emerging targets in cancer. Oncogene 39: 503-515, 2020.

4. Zhu Y, Zhang GN, Shi Y, Cui L, Leng XF and Huang JM: Perineural invasion in cervical cancer: Pay attention to the indications of nerve-sparing radical hysterectomy. Ann Transl Med 7: 203, 2019.

5. Magnon C, Hall SJ, Lin J, Xue X, Gerber L, Freedland SJ and Frenette PS: Autonomic nerve development contributes to prostate cancer progression. Science 341: 1236361, 2013.

6. Deborde S, Omelchenko T, Lyubchik A, Zhou Y, He S, McNamara WF, Chernichenko N, Lee SY, Barajas F, Chen $\mathrm{CH}$, et al: Schwann cells induce cancer cell dispersion and invasion. J Clin Invest 126: 1538-1554, 2016.

7. Ayala GE, Dai H, Powell M, Li R, Ding Y, Wheeler TM, Shine D, Kadmon D, Thompson T, Miles BJ, et al: Cancer-related axonogenesis and neurogenesis in prostate cancer. Clin Cancer Res 14: 7593-7603, 2008.

8. Dai H, Li R, Wheeler T, Ozen M, Ittmann M, Anderson M Wang Y, Rowley D, Younes M and Ayala GE: Enhanced survival in perineural invasion of pancreatic cancer: An in vitro approach. Hum Pathol 38: 299-307, 2007.

9. Albo D, Akay CL, Marshall CL, Wilks JA, Verstovsek G, Liu H, Agarwal N, Berger DH and Ayala GE: Neurogenesis in colorectal cancer is a marker of aggressive tumor behavior and poor outcomes. Cancer 117: 4834-4845, 2011

10. Huang D, Su S, Cui X, Shen X, Zeng Y, Wu W, Chen J, Chen F, $\mathrm{He} \mathrm{C}$, Liu J, et al: Nerve fibers in breast cancer tissues indicate aggressive tumor progression. Medicine (Baltimore) 93: e172, 2014.

11. Zhao Q, Yang Y, Liang X, Du G, Liu L, Lu L, Dong J, Han H and Zhang G: The clinicopathological significance of neurogenesis in breast cancer. BMC Cancer 14: 484, 2014.

12. Chowdary PD, Che DL and Cui B: Neurotrophin signaling via long-distance axonal transport. Annu Rev Phys Chem 63 571-594, 2012

13. Vanderhaeghen P and Cheng HJ: Guidance molecules in axon pruning and cell death. Cold Spring Harb Perspect Biol 2 $\mathrm{a} 001859,2010$

14. Mancino M, Ametller E, Gascon P and Almendro V: The neuronal influence on tumor progression. Biochim Biophys Acta 1816: 105-118, 2011.

15. Adriaenssens E, Vanhecke E, Saule P, Mougel A, Page A, Romon R, Nurcombe V, Le Bourhis X and Hondermarck H: Nerve growth factor is a potential therapeutic target in breast cancer. Cancer Res 68: 346-351, 2008.

16. Mandelker DL, Yamashita K, Tokumaru Y, Mimori K, Howard DL, Tanaka Y, Carvalho AL, Jiang WW, Park HL, Kim MS, et al: PGP9.5 promoter methylation is an independent prognostic factor for esophageal squamous cell carcinoma. Cancer Res 65: 4963-4968, 2005.

17. Lee YM, Lee JY, Kim MJ, Bae HI, Park JY, Kim SG and Kim DS: Hypomethylation of the protein gene product 9.5 promoter region in gallbladder cancer and its relationship with clinicopathological features. Cancer Sci 97: 1205-1210, 2006.

18. Wen W, Liu G, Jin K and Hu X: TGF- $\beta 1$ induces PGP9.5 expression in CAFs to promote the growth of colorectal cancer cells. Oncol Rep 37: 115-122, 2017.

19. Ohta T and Fukuda M: Ubiquitin and breast cancer. Oncogene 23 : 2079-2088, 2004.

20. Dollé L, Adriaenssens E, El Yazidi-Belkoura I, Le Bourhis X, Nurcombe V and Hondermarck H: Nerve growth factor receptors and signaling in breast cancer. Curr Cancer Drug Targets 4 : 463-470, 2004.

21. Bradshaw RA, Pundavela J, Biarc J, Chalkley RJ, Burlingame AL and Hondermarck H: NGF and ProNGF: Regulation of neuronal and neoplastic responses through receptor signaling. Adv Biol Regul 58: 16-27, 2015

22. Liss MA, Gordon A, Morales B, Osann K, Skarecky D, Lusch A, Zaldivar F and Ahlering TE: Urinary nerve growth factor as an oncologic biomarker for prostate cancer aggressiveness. Urol Oncol 32: 714-719, 2014

23. Mei F, Liu JY and Xue WC: Histological grading of invasive breast carcinoma: Nottingham histological grading system. Zhonghua Bing Li Xue Za Zhi 48: 659-664, 2019 (In Chinese).

24. Rao SJ, Rao JBM and Rao PJ: Immunohistochemical analysis of stromal fibrocytes and myofibroblasts to envision the invasion and lymph node metastasis in oral squamous cell carcinoma. J Oral Maxillofac Pathol 21: 218-223, 2017.

25. Livak KJ and Schmittgen TD: Analysis of relative gene expression data using real-time quantitative PCR and the 2(-Delta Delta C(T)) method. Methods 25: 402-408, 2001
26. Dikmen M: Comparison of the effects of curcumin and RG108 on NGF-induced PC-12 Adh cell differentiation and neurite outgrowth. J Med Food 20: 376-384, 2017.

27. Schimmelpfeng J, Weibezahn KF and Dertinger H: Quantification of NGF-dependent neuronal differentiation of PC-12 cells by means of neurofilament-L mRNA expression and neuronal outgrowth. J Neurosci Methods 139: 299-306, 2004.

28. Chan GKL, Hu WWH, Zheng ZX, Huang M, Lin YXY, Wang CY, Gong AGW, Yang XY, Tsim KWK and Dong TTX: Quercetin potentiates the NGF-induced effects in cultured PC 12 cells: Identification by HerboChips showing a binding with NGF. Evid Based Complement Alternat Med 1502457, 2018

29. Cai S, Cheng X, Liu Y, Lin Z, Zeng W, Yang C, Liu L, Chukwuebuka OA and Li W: EYA1 promotes tumor angiogenesis by activating the PI3K pathway in colorectal cancer. Exp Cell Res 367: 37-46, 2018

30. Ernst BP, Mikstas C, Stover T, Stauber R and Strieth S: Association of eIF4E and SPARC expression with lymphangiogenesis and lymph node metastasis in hypopharyngeal cancer. Anticancer Res 38: 699-706, 2018.

31. Wang J, Huang Y, Zhang J, Xing B, Xuan W, Wang H, Huang H, Yang $\mathrm{J}$ and Tang J: NRP-2 in tumor lymphangiogenesis and lymphatic metastasis. Cancer Lett 418: 176-184, 2018.

32. Zanotto-Filho A, Rajamanickam S, Loranc E, Masamsetti VP, Gorthi A, Romero JC, Tonapi S, Gonçalves RM, Reddick RL, Benavides R, et al: Sorafenib improves alkylating therapy by blocking induced inflammation, invasion and angiogenesis in breast cancer cells. Cancer Lett 425: 101-115, 2018.

33. Xia Y, Wei Y, Li ZY, Cai XY, Zhang LL, Dong XR, Zhang S, Zhang RG, Meng R, Zhu F and Wu G: Catecholamines contribute to the neovascularization of lung cancer via tumor-associated macrophages. Brain Behav Immun 81: 111-121, 2019.

34. Kim-Fuchs C, Le CP, Pimentel MA, Shackleford D, Ferrari D, Angst E, Hollande F and Sloan EK: Chronic stress accelerates pancreatic cancer growth and invasion: A critical role for beta-adrenergic signaling in the pancreatic microenvironment. Brain Behav Immun 40: 40-47, 2014.

35. Lamkin DM, Sloan EK, Patel AJ, Chiang BS, Pimentel MA, Ma JC, Arevalo JM, Morizono K and Cole SW: Chronic stress enhances progression of acute lymphoblastic leukemia via $\beta$-adrenergic signaling. Brain Behav Immun 26: 635-641, 2012.

36. Liu Y, Yu X and Zhuang J: Epinephrine stimulates cell proliferation and induces chemoresistance in myeloma cells through the $\beta$-adrenoreceptor in vitro. Acta Haematol 138: 103-110, 2017.

37. Wu FQ, Fang T, Yu LX, Lv GS, Lv HW, Liang D, Li T, Wang CZ, Tan YX, Ding J, et al: ADRB2 signaling promotes HCC progression and sorafenib resistance by inhibiting autophagic degradation of HIFlalpha. J Hepatol 65: 314-324, 2016.

38. Lu R, Fan C, Shangguan W, Liu Y, Li Y, Shang Y, Yin D, Zhang S, Huang Q, Li X, et al: Neurons generated from carcinoma stem cells support cancer progression. Signal Transduct Target Ther 2: 16036, 2017.

39. Marusyk A and Polyak K: Tumor heterogeneity: Causes and consequences. Biochim Biophys Acta 1805: 105-117, 2010.

40. West NR, McCuaig S, Franchini F and Powrie F: Emerging cytokine networks in colorectal cancer. Nat Rev Immunol 15: 615-629, 2015.

41. Mantovani A, Barajon I and Garlanda C: IL-1 and IL-1 regulatory pathways in cancer progression and therapy. Immunol Rev 281: 57-61, 2018.

42. Berraondo P, Sanmamed MF, Ochoa MC,Etxeberria I, Aznar MA, Pérez-Gracia JL, Rodríguez-Ruiz ME, Ponz-Sarvise M, Castañón E and Melero I: Cytokines in clinical cancer immunotherapy. Br J Cancer 120: 6-15, 2019.

43. Galdiero MR, Marone G and Mantovani A: Cancer inflammation and cytokines. Cold Spring Harb Perspect Biol 10: a028662, 2018.

44. Najafi M, Goradel NH, Farhood B, Salehi E, Solhjoo S, Toolee H, Kharazinejad E and Mortezaee K: Tumor microenvironment: Interactions and therapy. J Cell Physiol 234: 5700-5721, 2019.

45. Yao M, Brummer G, Acevedo D and Cheng N: Cytokine regulation of metastasis and tumorigenicity. Adv Cancer Res 132: 265-367, 2016.

46. Hong JT, Son DJ, Lee CK, Yoon DY, Lee DH and Park MH: Interleukin 32, inflammation and cancer. Pharmacol Ther 174: 127-137, 2017.

47. Setrerrahmane S and Xu H: Tumor-related interleukins: Old validated targets for new anti-cancer drug development. Mol Cancer 16: 153, 2017. 
48. Folkman J, Merler E, Abernathy C and Williams G: Isolation of a tumor factor responsible for angiogenesis. J Exp Med 133: 275-288, 1971

49. FischerC,Jonckx B,Mazzone M,Zacchigna S,LogesS,Pattarini L, Chorianopoulos E, Liesenborghs L, Koch M, De Mol M, et al: Anti-PlGF inhibits growth of VEGF(R)-inhibitor-resistant tumors without affecting healthy vessels. Cell 131: 463-475, 2007.

50. Fischer C, Mazzone M, Jonckx B and Carmeliet P: FLT1 and its ligands VEGFB and PIGF: Drug targets for anti-angiogenic therapy? Nat Rev Cancer 8: 942-956, 2008.

51. Ellis LM and Hicklin DJ: VEGF-targeted therapy: Mechanisms of anti-tumour activity. Nat Rev Cancer 8: 579-591, 2008

52. Alitalo K, Tammela T and Petrova TV: Lymphangiogenesis in development and human disease. Nature 438: 946-953, 2005.

53. Stacker SA, Baldwin ME and Achen MG: The role of tumor lymphangiogenesis in metastatic spread. FASEB J 16: 922-934, 2002.

54. Lala PK, Nandi P and Majumder M: Roles of prostaglandins in tumor-associated lymphangiogenesis with special reference to breast cancer. Cancer Metastasis Rev 37: 369-384, 2018.

55. Dieterich LC and Detmar M: Tumor lymphangiogenesis and new drug development. Adv Drug Deliv Rev 99: 148-160, 2016.

56. Garnier L, Gkountidi AO and Hugues S: Tumor-associated lymphatic vessel features and immunomodulatory functions. Front Immunol 10: 720, 2019.

57. Paduch R: The role of lymphangiogenesis and angiogenesis in tumor metastasis. Cell Oncol (Dordr) 39: 397-410, 2016.

58. Achen MG and Stacker SA: Tumor lymphangiogenesis and metastatic spread-new players begin to emerge. Int J Cancer 119 1755-1760, 2006.

59. Seifert P, Benedic M and Effert P: Nerve fibers in tumors of the human urinary bladder. Virchows Arch 440: 291-297, 2002.

60. Seifert P and Spitznas M: Axons in human choroidal melanoma suggest the participation of nerves in the control of these tumors. Am J Ophthalmol 133: 711-713, 2002.

61. Ventura S, Pennefather J and Mitchelson F: Cholinergic innervation and function in the prostate gland. Pharmacol Ther 94 93-112, 2002

62. Mitchell BS, Schumacher U, Stauber VV and Kaiserling E: Are breast tumours innervated? Immunohistological investigations using antibodies against the neuronal marker protein gene product 9.5 (PGP 9.5) in benign and malignant breast lesions. Eur J Cancer 30A: 1100-1103, 1994.

63. Kayahara M, Nakagawara H, Kitagawa $\mathrm{H}$ and Ohta T: The nature of neural invasion by pancreatic cancer. Pancreas 35: 218-223, 2007.

64. Ayala GE, Wheeler TM, Shine HD, Schmelz M, Frolov A, Chakraborty S and Rowley D: In vitro dorsal root ganglia and human prostate cell line interaction: Redefining perineural invasion in prostate cancer. Prostate 49: 213-223, 2001.
65. Godbout JP and Glaser R: Stress-induced immune dysregulation: Implications for wound healing, infectious disease and cancer. J Neuroimmune Pharmacol 1: 421-427, 2006.

66. Lee JW, Shahzad MM, Lin YG, Armaiz-Pena G, Mangala LS, Han HD, Kim HS, Nam EJ, Jennings NB, Halder J, et al: Surgical stress promotes tumor growth in ovarian carcinoma. Clin Cancer Res 15: 2695-2702, 2009.

67. Thaker PH, Han LY, Kamat AA, Arevalo JM, Takahashi R, Lu C, Jennings NB, Armaiz-Pena G, Bankson JA, Ravoori M, et al: Chronic stress promotes tumor growth and angiogenesis in a mouse model of ovarian carcinoma. Nat Med 12: 939-944, 2006.

68. Entschladen F, Drell TL IV, Lang K, Joseph J and Zaenker KS: Tumour-cell migration, invasion, and metastasis: Navigation by neurotransmitters. Lancet Oncol 5: 254-258, 2004.

69. Geldof AA, Van Haarst EP and Newling DW: Neurotrophic factors in prostate and prostatic cancer. Prostate Cancer Prostatic Dis 1: 236-241, 1998.

70. Ricci A, Greco S, Mariotta S, Felici L, Bronzetti E, Cavazzana A, Cardillo G, Amenta F, Bisetti A and Barbolini G: Neurotrophins and neurotrophin receptors in human lung cancer. Am J Respir Cell Mol Biol 25: 439-446, 2001.

71. Dollé L, El Yazidi-Belkoura I, Adriaenssens E, Nurcombe V and Hondermarck H: Nerve growth factor overexpression and autocrine loop in breast cancer cells. Oncogene 22: 5592-5601, 2003.

72. Chédotal A, Kerjan G and Moreau-Fauvarque C: The brain within the tumor: New roles for axon guidance molecules in cancers. Cell Death Differ 12: 1044-1056, 2005.

73. Sofroniew MV, Howe CL and Mobley WC: Nerve growth factor signaling, neuroprotection, and neural repair. Annu Rev Neurosci 24: 1217-1281, 2001.

74. Melincovici CS, Boşca AB, Şuşman S, Mărginean M, Mihu C, Istrate M, Moldovan IM, Roman AL and Mihu CM: Vascular endothelial growth factor (VEGF)-key factor in normal and pathological angiogenesis. Rom J Morphol Embryol 59: 455-467, 2018.

75. Deyama S, Bang E, Kato T, Li XY and Duman RS: Neurotrophic and antidepressant actions of brain-derived neurotrophic factor require vascular endothelial growth factor. Biol Psychiatry 86: 143-152, 2019.

76. Kutcher ME, Klagsbrun M and Mamluk R: VEGF is required for the maintenance of dorsal root ganglia blood vessels but not neurons during development. FASEB J 18: 1952-1954, 2004.

This work is licensed under a Creative Commons Attribution-NonCommercial-NoDerivatives 4.0 International (CC BY-NC-ND 4.0) License. 